\title{
Investigations on the Rust Disease Prevalence on Cowpea in Mandya District and Evaluation of Cowpea Genotypes for its Resistance
}

\author{
Jayashree Bamabalwad ${ }^{1}$, N.S. Pankaja ${ }^{1}$, G. Sugeetha ${ }^{2}$, J. Mahadev ${ }^{3}$ and Suryakanth $^{1 *}$ \\ ${ }^{1}$ Department of Plant Pathology, ${ }^{2}$ Department of Entomology, ${ }^{3}$ Department of Environmental \\ Sciences, College of Agriculture, V. C. Farm, Mandya, India \\ *Corresponding author
}

\section{Keywords}

Rust, Uromyces phaseoli var. vignae, Mandya, Kharif and Per cent disease index

Article Info

Accepted:

10 October 2019

Available Online:

10 November 2019
Cowpea is an important grain legume crop. Among various diseases, rust caused by Uromyces phaseoli var. vignae (Barclay) Arthuris one of the major constraints of cowpea production across all cowpea growing areas of the state, thereby causing severe yield loss. The present study aimed at determining the severity of cowpea rust in six taluks of Mandya district viz., Mandya, Maddur, Malavalli, Pandavapura, Srirangapatna and Krishnarajpet during Kharif 2017. The maximum mean disease severity was recorded in Mandyataluk (39.14\%) followed by Maddur taluk (34.61\%) and Pandavapura taluk (31.83\%) and minimum mean disease severity of 20.76 per cent was observed in Krishnarajapet taluk followed by Srirangapatna taluk (22.10\%) and Malavalli taluk (27.56\%). In order to identify the resistant sources against this disease an experiment was conducted to evaluate 57 genotypes under field conditions during Kharif 2017 at College of Agriculture, V. C. Farm, Mandya (University of Agricultural Sciences, Bengaluru). The disease severity varied from 0.13 to $81.45 \%$. Out of fifty seven genotypes screened none of them were found to be immune. However, 16 genotypes were resistant, 23 genotypes were moderately resistant, 10 genotypes were moderately susceptible, 7 genotypes were susceptible and variety $\mathrm{C}$ 152 showed highly susceptible reaction against rust.

\section{Introduction}

Cowpea (Vigna unguiculata (L.)Walp.) is an important annual legume among the pulse crops grown in tropical and sub-tropical countries of the world. It is grown through-out India particularly in the Central and Peninsular regions. It is a popular crop due to its rich and cheap sources of high quality protein of about 24.8 per cent, 1.8 per cent fat and 60.3 per cent carbohydrates. It is referred to as 'vegetable meat' because it contains high amounts of protein in grain with good biological value on dry weight basis (Gopalan et al., 2007). Cowpea occupies 3.9 mha of area with $2.2 \mathrm{mt}$ production and $564 \mathrm{~kg} \mathrm{ha}^{-1}$ 
productivity in India (Anon., 2015). In Karnataka, it occupies an area of $0.97 \mathrm{~m}$ ha with production of $0.43 \mathrm{~m} \mathrm{t}$ and productivity of $462 \mathrm{~kg} \mathrm{ha}^{-1}$ (Anon., 2013). Cowpea is reported to be infected by more than ten diseases. Rust of cowpea caused by Uromycesphaseolis var. vignae (Barclay) Arthuris widely distributed throughout the country and is responsible for heavy reduction in yield (Chandrashekaret al., 1988). The disease is observed in severe form in July sown crop during southwest monsoon resulting in considerable yield loss (Chandrasekhar et al., 1989).

This disease is widespread in cowpea growing areas of the world and is reported from at least 20 countries causing $10-15$ per cent annual losses (Anilkumaret al., 1989). In most of the parts of Karnataka, rust is an economically important and serious disease which affects the production of cowpea. The disease was reported to occur in Dharwad and Mysore (Rangaswamy etal., 1989). As the disease progresses, premature defoliation leading to reduced seed size and severe yield loss has been observed (Honnuret al., 2016). Also the significance of disease depends on prevalence of virulent races and their affinity with the genetic constitution of the host in the prevailing environment. The present investigation was undertaken to know the disease incidence and to screen the genotypes against rust disease.

\section{Materials and Methods}

A roving survey was conducted during Kharif season of 2016-17 in major cowpea growing areas of Mandya district. In each taluk2-7 villages were selected and in each village one to two fields were surveyed for recording the severity of cowpea rust. In each field 50 plants were selected at random for recording the disease severity. Disease scoring is done as per Mayee and Datara (1986) 0-9 scale and
Per cent Disease Index (PDI) was calculated using the below mentioned formula.

The cowpea genotypes were screened against rust under field conditions during Kharif 2017 at College of Agriculture V. C. Farm, Mandya (University of Agricultural Sciences, Bengaluru). Each genotype was sown in two rows of $3 \mathrm{~m}$ length with $45 \times 10 \mathrm{~cm}$ spacing and regular agronomic practices were followed. The observations were recorded by using 0-9 scale (Mayee and Datar, 1986) by selecting 5 plants in each row of each genotype. Percent disease index (PDI) will be calculated using the formula mentioned below.

\section{$\mathrm{PDI}=$}

Sum of all disease ratings

Total number of ratings $\times 100$

xMaximum disease grade

\section{Results and Discussion}

A total of six taluks were selected. In Mandyataluk, seven villages were surveyed wherein the highest average disease severity was recorded at Mandya (48.45\%) followed by Shivalli village $(42.44 \%)$, V. C. Farm $(40.75 \%)$ and Dudda $(38.33 \%)$. However, least average disease severity was observed in Mallanayakanakatte village (33.48\%) followed by Ganadalu (34.44\%) and Holalu village $(36.11 \%)$. Further the average disease severity of $39.14 \%$ was recorded in Mandya taluk.

A total of three villages were surveyed in Maddur taluk. The average disease severity of $34.61 \%$ was observed in this taluk. The highest average disease severity of $35.50 \%$ was recorded in Maddur followed by Honnalagere village $(35.00 \%)$ and the lowest average disease severity was obtained in Bharatinagar village (33.33\%). An average disease severity of $31.83 \%$ was recorded from 
the six villages of Pandavapura taluk. Among the villages surveyed Cheluvarawinakoppalu recorded highest average disease severity of $34.44 \%$ followed by Pandavapura (33.25\%), Kanakanamaradi (31.66\%) and Jakkanahalli $(31.10 \%)$ whereas the lowest average severity of disease was observed in Chinakurali $(30.00 \%)$ followed by Melukote village $(30.55 \%)$.

Ten villages were surveyed in Malavalli taluk wherein the average disease severity of $27.56 \%$ was observed. The highest average disease severity was observed in Malavalli $(32.20 \%)$ followed by Dubnalli village (32.0\%), Devipura (31.85\%), Kagepura $(31.55 \%)$ and Dundanahalli $(30.0 \%)$ The lowest average disease severity was obtained in Nidagatta village $(20.80 \%)$ followed by Anjadoddi village $(21.4 \%)$, Talagawadi (23.33\%), Kandegala (25.00\%) and Hosalli $(27.50 \%)$.

In Srirangapatna taluk, the average disease severity of $22.1 \%$ was recorded from the two villages surveyed. The survey revealed that the highest average disease severity of $24.20 \%$ in Neralekere village. The least average disease severity of $20.0 \%$ was observed in Srirangapatna.

In Krishnarajpet taluk, the average disease severity of $20.76 \%$ was recorded from two villages surveyed. The highest average disease severity was observed in Krishnarajapet $(23.20 \%)$ whereas the lowest average disease severity of rust was obtained in Machanahalli village $(18.33 \%)$

Among the taluks surveyed in Mandya district, the results revealed the highest average disease severity in Mandya taluk (39.14\%) followed by Maddur taluk (34.61\%) and Pandavapura taluk (31.83\%). The lowest average disease severity was recorded in Krishnarajapet taluk $(20.76 \%)$ followed by Srirangapatna taluk (22.1\%). Among the different villages of six taluks, the highest average disease severity was observed in Mandya village ( $48.45 \%$ ) followed by Shivalli village of Mandyataluk (42.44\%), whereas the lowest average disease severity was recorded in Srirangapatna village $(20.0 \%)$ of Srirangapatna taluk followed by Anjadoddi village $(21.4 \%)$ of Malavalli taluk (Table 14).

Table.1 Disease scoring scale description (Mayee and Datar, 1986)

\begin{tabular}{|c|c|c|}
\hline Score & Description & Category \\
\hline $\mathbf{0}$ & No symptoms on leaves & Immune (I) \\
\hline 1 & $\begin{array}{l}\text { Small, round, powdery brown uredospores covering } \\
1 \% \text { or less of leaf area }\end{array}$ & Resistant (R) \\
\hline 3 & Typical uredospore covering $1-10 \%$ of the leaf area & $\begin{array}{l}\text { Moderately Resistant } \\
\text { (MR) }\end{array}$ \\
\hline 5 & Typical uredospores covering $11-25 \%$ of the leaf area & $\begin{array}{c}\text { Moderately Susceptible } \\
\text { (MS }\end{array}$ \\
\hline 7 & Typical uredospores covering $26-50 \%$ of the leaf area & Susceptible (S) \\
\hline 9 & $\begin{array}{l}\text { Typical uredospores covering } 51 \% \text { or more of leaf } \\
\text { area }\end{array}$ & Highly Susceptible (HS) \\
\hline
\end{tabular}


Table.2 The disease severity of cowpea rust in Mandya district

\begin{tabular}{|c|c|c|c|c|c|}
\hline Taluks & Villages & Stage of crop & Variety & $\begin{array}{c}\text { Mean } \\
\text { disease } \\
\text { severity } \\
(\%)\end{array}$ & $\begin{array}{c}\text { Mean } \\
\text { disease } \\
\text { severity of } \\
\text { Taluks } \\
(\%)\end{array}$ \\
\hline \multirow[t]{7}{*}{ Mandya } & Holalu & Pod development & C-152 & 36.11 & \multirow[t]{7}{*}{39.14} \\
\hline & Dudda & Flowering & C-152 & 38.33 & \\
\hline & Mallanayakanakatte & Pod development & C-152 & 33.48 & \\
\hline & Ganadalu & Pod development & C-152 & 34.44 & \\
\hline & V. C. Farm & Flowering & C-152 & 40.75 & \\
\hline & Shivalli & Flowering & C-152 & 42.44 & \\
\hline & Mandya & Flowering & C-152 & 48.45 & \\
\hline \multirow[t]{3}{*}{ Maddur } & Honnalagere & Flowering & C-152 & 35.00 & \multirow[t]{3}{*}{34.61} \\
\hline & Bharatinagar & Flowering & C-152 & 33.33 & \\
\hline & Maddur & Flowering & C-152 & 35.50 & \\
\hline \multirow[t]{6}{*}{ Pandavapura } & Chinakurali & Flowering & Pantolab-2 & 30.00 & \multirow[t]{6}{*}{31.83} \\
\hline & Kanakanamaradi & Pod development & Pantolab-2 & 31.66 & \\
\hline & $\begin{array}{c}\text { Cheluvarawinakoppal } \\
\mathrm{u}\end{array}$ & Pod development & Pantolab-2 & 34.44 & \\
\hline & Melukote & Flowering & Pantolab-2 & 30.55 & \\
\hline & Jakkanahalli & Flowering & Pantolab-2 & 31.10 & \\
\hline & Pandavapura & Flowering & Pantolab-2 & 33.25 & \\
\hline \multirow[t]{10}{*}{ Malavalli } & Nidagatta & Flowering & Pantolab-2 & 20.80 & \multirow[t]{10}{*}{27.56} \\
\hline & Anjadoddi & Flowering & Pantolab-2 & 21.40 & \\
\hline & Kandegala & Flowering & Pantolab-2 & 25.00 & \\
\hline & Hosalli & Flowering & Pantolab-2 & 27.50 & \\
\hline & Talagawadi & Flowering & Pantolab-2 & 23.33 & \\
\hline & Dubnalli & Flowering & Pantolab-2 & 32.00 & \\
\hline & Devipura & Flowering & Pantolab-2 & 31.85 & \\
\hline & Dundanahalli & Flowering & Pantolab-2 & 30.00 & \\
\hline & Kagepura & Flowering & Pantolab-2 & 31.55 & \\
\hline & Malavalli & Flowering & Pantolab-2 & 32.20 & \\
\hline \multirow[t]{2}{*}{ Srirangapatna } & Neralekere & Flowering & C-152 & 24.20 & \multirow[t]{2}{*}{22.10} \\
\hline & Srirangapatna & Flowering & C-152 & 20.00 & \\
\hline \multirow[t]{2}{*}{ Krishnarajapet } & Machanahalli & Flowering & C-152 & 18.33 & \multirow[t]{2}{*}{20.76} \\
\hline & Krishnarajapet & Flowering & C-152 & 23.20 & \\
\hline
\end{tabular}


Table.3 Disease severity of cowpea genotypes screened under field conditions

\begin{tabular}{|c|c|c|c|c|c|}
\hline Sl. No. & Genotypes & $\begin{array}{c}\text { Per cent } \\
\text { disease inde } \\
\text { (PDI) }\end{array}$ & Sl. No. & Genotypes & $\begin{array}{c}\text { Per cent disease } \\
\text { index (PDI) }\end{array}$ \\
\hline $\mathbf{1 .}$ & AV-5 & 26.77 & 30. & PV-3 & 14.54 \\
\hline $\mathbf{2 .}$ & 27 & 12.00 & 31. & ArkaSuman & 4.57 \\
\hline $\mathbf{3 .}$ & V-16 & 0.50 & 32. & Kashiunnati & 0.48 \\
\hline $\mathbf{4 .}$ & C152XV16 & 0.23 & 33. & IC-206240 & 0.57 \\
\hline $\mathbf{5 .}$ & K4-1 & 01.45 & 34. & PKB-4-2 & 2.44 \\
\hline $\mathbf{6 .}$ & 120 P1-1-1 & 5.55 & 35. & IC-402180 & 0.21 \\
\hline $\mathbf{7 .}$ & $17-1$ & 6.74 & 36. & PKB-6-2 & 0.66 \\
\hline $\mathbf{8 .}$ & 61 & 6.68 & 37. & APC-668-1 & 7.78 \\
\hline $\mathbf{9 .}$ & 34 & 30.00 & 38. & NBC-25 & 3.56 \\
\hline $\mathbf{1 0 .}$ & 22 & 5.75 & 39. & C-720 & 9.88 \\
\hline $\mathbf{1 1 .}$ & GC-3 & 13.44 & 40. & NBC-38 & 4.35 \\
\hline $\mathbf{1 2 .}$ & IC-2027 & 15.75 & 41. & EC-458473 & 20.98 \\
\hline $\mathbf{1 3 .}$ & $27749(25)$ & 20.00 & 42. & Lola & 24.65 \\
\hline $\mathbf{1 4 .}$ & 59 & 0.13 & 43. & IC-402104 & 40.88 \\
\hline $\mathbf{1 5 .}$ & NBC-21 & 23.44 & 44. & $15 P 2-3$ & 5.64 \\
\hline $\mathbf{1 6 .}$ & K4-2 & 0.34 & 45. & IC-2591054 & 6.75 \\
\hline $\mathbf{1 7 .}$ & IC-402175 & 3.68 & 46. & $21-2$ & 0.45 \\
\hline $\mathbf{1 8 .}$ & PKB-4-3 & 0.45 & 47. & $13 P 1-2$ & 3.33 \\
\hline $\mathbf{1 9 .}$ & $35-1$ & 4.56 & 48. & PKB-6-4 & 0.89 \\
\hline $\mathbf{2 0 .}$ & KBC-2 & 0.52 & 49. & IC-58905 & 0.16 \\
\hline $\mathbf{2 1 .}$ & IC-25105 & 3.34 & 50. & PGCP-11 & 45.43 \\
\hline $\mathbf{2 2 .}$ & AV-7 & 18.94 & 51. & Bhagya & 4.50 \\
\hline $\mathbf{2 3 .}$ & AV-6 & 2.48 & 52. & IC-249593 & 0.13 \\
\hline $\mathbf{2 4 .}$ & PKB-3-1 & 3.22 & 53. & V-604-7-29-3 & 34.50 \\
\hline $\mathbf{2 5 .}$ & PKB-2 & 16.76 & 54. & Genotype-36 & 32.34 \\
\hline $\mathbf{2 6 .}$ & EC-458483 & 0.32 & 55. & UPC-5286 & 2.45 \\
\hline $\mathbf{2 7 .}$ & 120 P1-1-2 & 6.33 & 56. & PGCP-6 & 48.75 \\
\hline $\mathbf{2 8 .}$ & PKB-4-4 & 3.36 & 57. & C-152 & 81.45 \\
\hline $\mathbf{2 9 .}$ & EC-458480 & 0.25 & & & \\
\hline & & & & & \\
\hline
\end{tabular}


Table.4 Reaction of cowpea genotypes to U. phaseoli var. Vignae under field conditions

\begin{tabular}{|c|c|c|c|}
\hline Reaction & Description & $\begin{array}{l}\text { No. of } \\
\text { genotypes }\end{array}$ & Genotypes \\
\hline Immune & No symptoms on leaves & 0 & - \\
\hline Resistant & $\begin{array}{l}\text { Small, round, powdery brown } \\
\text { uredospores covering } 1 \% \text { or } \\
\text { less of leaf area }\end{array}$ & 16 & $\begin{array}{c}\text { C152×V16, 59, K4-2, PKB4-3, } \\
\text { Kashiunnati, IC206240, PKB6-2, V-16, } \\
\text { EC458483, PKB6-4, EC458480, KBC-2, } \\
\text { IC402180, 21-2, IC58905, IC249593 }\end{array}$ \\
\hline $\begin{array}{l}\text { Moderately } \\
\text { Resistant }\end{array}$ & $\begin{array}{l}\text { Typical uredospore covering } \\
1-10 \% \text { of the leaf area }\end{array}$ & 23 & $\begin{array}{c}\text { K4-1, 120P1-1-1, 17-1, 61, 22, IC402175, } \\
\text { 35-1, IC25105, AV-16, PKB3-1, 120P1- } \\
\text { 1-2, PKB4-4, Arkasuman, PKB4-2, } \\
\text { APC668-1, NBC25, C-720, NBC-38, } \\
\text { 15P2-3, IC2591054, 13P1-2, Bhagya, } \\
\text { UPC-5286. }\end{array}$ \\
\hline $\begin{array}{l}\text { Moderately } \\
\text { Susceptible }\end{array}$ & $\begin{array}{l}\text { Typical uredospores covering } \\
11-25 \% \text { of the leaf area }\end{array}$ & 10 & $\begin{array}{l}\text { 27, GC-3, IC2027, 27749(25), NBC-21, } \\
\text { AV-7, PKB-2, PV-3, EC458473, Lola }\end{array}$ \\
\hline Susceptible & $\begin{array}{l}\text { Typical uredospores covering } \\
26-50 \% \text { of the leaf area }\end{array}$ & 7 & $\begin{array}{l}\text { PGCP-6, AV-5, 34, IC402104, PGCP- } \\
\text { 11,V-604-7-29-3, Genotype-36 }\end{array}$ \\
\hline $\begin{array}{c}\text { Highly } \\
\text { Susceptible }\end{array}$ & $\begin{array}{l}\text { Typical uredospores covering } \\
51 \% \text { or more of leaf area }\end{array}$ & 1 & C-152 \\
\hline
\end{tabular}

In the screening experiment, the results thus obtained revealed that the disease severity ranged between 0.13 to 81.45 per cent. The highest disease severity was recorded in the susceptible check C-152 variety $(81.45 \%)$ followed by PGCP-6 (48.75\%), PGCP-11 (45.43\%), IC-402104 (40.88\%), V-604-7-29-3 (34.50\%) and Genotype-36 (32.34\%).

Whereas, least disease severity of 0.13 per cent was recorded in IC-249593 and 59 followed by IC-58905 (0.16\%), IC-402180 $(0.21 \%), \quad \mathrm{C} 152 \times \mathrm{V} 16 \quad(0.23 \%), \quad$ EC-45480 $(0.25 \%), \quad$ EC-458483 (0.32\%) and K4-2 $(0.34 \%)$.

Out of fifty seven genotypes screened none of them were found to be immune. However, sixteen genotypes viz., C152×V16, 59, K4-2, PKB4-3, Kashiunnati, IC206240, PKB6-2, V16, EC458483, PKB6-4, EC458480, KBC-2, IC402180, 21-2, IC58905, IC249593were found to be resistant to rust with disease severity ranging between 0.13 to 0.89 per cent.
Twenty three genotypes viz., K4-1, 120P1-1-1, 17-1, 61, 22, IC402175, 35-1, IC25105, AV16, PKB3-1, 120P1-1-2, PKB4-4, ArkaSuman, PKB4-2, APC668-1, NBC25, C720, NBC-38, 15P2-3, IC2591054, 13P1-2, Bhagya, UPC-5286 were found to be moderately resistant with severity ranging from 1.45 to 9.88 per cent.

Ten genotypes viz., 27, GC-3, IC2027, 27749(25), NBC-21, AV-7, PKB-2, PV-3, EC458473, Lola found to be moderately susceptible with disease severity ranging from 12 to 24.65 per cent and seven genotypes viz., PGCP-6, AV-5, 34,IC402104, PGCP-11,V604-7-29-3, Genotype-36 were found to be susceptible with disease severity ranging from 26.77 to 48.75 per cent. The variety C- 152 showed highly susceptible reaction for rust with per cent disease severity of 81.45 .

The survey results revealed that highest average disease severity in Mandya taluk which may be due to availability of the 
inoculums the environmental conditions that must have favored the development of inoculum that subsequently lead to increase in severity of rust. These results are in accordance with those reported by Abdullah $e t$ al., (2011) where he observed the disease severity of 26.50 to 50.00 per cent in susceptible C-152 variety grown during Kharif-2008, 2009 and 2010 in Bengaluru, Dharwad, Mandya and Pattambi locations. Similar results were recorded by Hiremath $e t$ al., (1987) wherein, he recorded a rust severity upto 90-100 per cent in Kharif season, caused by same pathogen species (Uromyces cicerisarietini) in chickpea crop Further the data reveals the highest average disease severity during flowering stage of the crop. The results are in accordance with Negussie and Pretorius (2008) who reported that flowering stage of pea is most susceptible to rust disease caused by Uromyces viciae-fabae which found to affect the fertile flowers and hence, the number of pods formed.

The host plant resistance is an important choice in the management of crop diseases. As its use in farming is the very effective, simple and economical means in managing the disease. Therefore, identification of resistant sources forms one of the criteria in resistant breeding program. Over 300 races or pathotypes of rust are recognized indicating the broad variability of the rust fungus (Araya et al., 2004). In the present study 57 genotypes of cowpea were screened for rust resistance under natural epiphytotic conditions. None of the genotypes showed immune reaction. However, genotypes C152×V16, 59, K4-2, PKB4-3, Kashiunnati, IC206240, PKB6-2, V16, EC458483, PKB6-4, EC458480, KBC-2, IC402180, 21-2, IC58905 and IC249593were resistant. In general, over all disease incidence was very high. Similar results were also reported by Anilkumar et al., 1989 and Kale (1992) wherein they observed that among 24 cowpea genotypes screened five genotypes showed immune reaction against rust and $\mathrm{C}$ 152 was found to be highly susceptible with 77.24 per cent disease severity. Similarly, Uma and Salimath (2003) also reported that some of varieties of cowpea, such as C-11, C70 and KM-1 were highly resistant to rust disease.

Realizing the economic importance of the disease and that survey provides an extensive information about the disease severity, a survey on the disease severity was carried out in farmer's fields of Mandya district. Six taluks of Mandya district were surveyed and the disease severity ranged between 20.76 to 39.14 per cent, and that all the villages surveyed revealed the prevalence of the disease. Therefore, understanding the relationship between disease severity and yield loss is useful for the management of the disease.

The present work also demonstrates that the disease severity as high as 81.45 in the susceptible check $\mathrm{C}-152$, thus revealing the important of this disease in cowpea. In this study, genotypes constituting a pool of varieties resistant to rust have been identified and conserved. Among the 57 genotypes, 16 of them were found to be resistant and 23 moderately resistant to the disease. Further research is recommended on the varieties mentioned above at different places for further reliability. Also that, comparison of plant yield with disease can be done.

\section{References}

Abdullah, A., Somashekhar, Y. M. and Uma, M. S., 2011, Assessment of cowpea [Vigna unguiculata (L.)Walp] genotypes for partial resistance to rust (Uromyces phaseoli var. vignae) Advances in Plant Disease Research (NSRAPDR), Department of Plant Pathology, Faculty of Agriculture, 
Annamalai Univ. Annamalai Nagar, Tamilnadu.

Anilkumar, B. T., Chandrashekar, M. and Veerappa, K. B., 1989, Assessment of cowpea genotypes for multiple disease resistance (Abs).Indian Phytopathol., 42: 334 .

Annonymous, (2013), http://www.nabard.org. Annonymous, (2015), Http://Www.Nabard.Org.

Araya, C.M., Alleyne, A.T., Steadman, J.R., Eskridge, K.M. and Coyne, D.P., 2004.Phenotypic and genotypic characterization of Uromyces appendiculatus from Phaseolus vulgaris in the Americas. Plant Disease 88:830-836.

Chandrashekar, M., Anilkumar, T. B. and Saifulla, M., Salimath, P. M., 1988, Leaf rust epidemics of certain promising cowpea varieties compared by using Logistic and Gompertz models. Trop. Agric., 65: 37-40.

Chandrashekar, M., Anilkumar, T. B. and Saifulla, M., 1989, Effect of different dates of cowpea on the severity of leaf rust caused by Uromyces phaseoli var. vignae.Trop. Agric., 65: 149-152.

Elawad, H. O. A. and Hall, A. E., 1987, Influences of early and late nitrogen fertilization on yield and nitrogen fixation of cowpea under well-watered and dry field conditions. Field Crops Res., 15:229-244.
Gopalan, C., Rama, S.B.V. and BALASUBRAMANIAN, S. C., 2007, Nutritive value of Indian Foodsrevised edition. National Institute of Nutrition, Indian Council of Medical Research, Hyderabad, India.P. 50.

Hiremath, P. C., Reddy, B. M. R., Deshpande, V. P. and Hegde, R. K., 1987, Occurrence of rust epidemic on bengalgram in Karnataka. Curr. Res. Univ. Agril. Sci., Bangalore, Karnataka (India), 16(12): 171-172.

Honnur, R. B., Yadahalli, K. B. and Jahagirdar, S. 2016, Identification of susceptible stage for rust in cowpea, Biochem. Cell Arch.16(1): 141-143

Kale, J. K., 1992, Studies on some aspects of the rust of cowpea (Vigna unguiculata (L) Walp) caused by Uromyces phaseoli var.vignae (Barcl.) Arth. M. Sc. (Agri.) Thesis, Univ. Agric. Sci. Dharwad, Karnataka (India).

Mayee, C. D. and Datar, V. V., 1986, Phytopathometry, Technical Bulletin-1 (Special Bulletin-3) Marathwada Agric. Univ. Parbhani.

Negussie, T. G. and Pretorius, Z. A., 2008, Yield loss of lentil caused by Uromyces viciae-fabae. South African J. Plant Soil., 25(1): 32-41.

Uma, M. S. and Salimath, 2003, Inheritance of rust resistance in cowpea (Vigna unguiculata (L) Walp.). Indian $J$. Genet., 63: 167-168.

\section{How to cite this article:}

Jayashree Bamabalwad, N.S. Pankaja, G. Sugeetha, J. Mahadev and Suryakanth. 2019. Investigations on the Rust Disease Prevalence on Cowpea in Mandya District and Evaluation of Cowpea Genotypes for its Resistance. Int.J.Curr.Microbiol.App.Sci. 8(11): 1126-1133. doi: https://doi.org/10.20546/ijcmas.2019.811.132 